\title{
WSPÓŁPRACA STANÓW ZJEDNOCZONYCH I UNII EUROPEJSKIEJ W DZIEDZINIE ZWALCZANIA TERRORYZMU - RAZEM MIMO RÓŻNIC (LATA 2001-2010)
}

W listopadzie 2010 roku światowe media skupiły swą uwagę na dwóch kwestiach. Pierwszą była publikacja przez portal internetowy WikiLeaks poufnych depesz dyplomatycznych przesyłanych między Departamentem Stanu USA a ambasadami USA. Natomiast drugą sprawą były prowokacje zbrojne rządu Koreańskiej Republiki Ludowo-Demokratycznej (KRLD) wymierzone w Republikę Korei (RK).

Oba wydarzenia przykuły uwagę opinii publicznej, jednak z perspektywy współpracy Unii Europejskiej i Stanów Zjednoczonych w zwalczaniu terroryzmu dużo ważniejszym problemem stała się publikacja części poufnych lub tajnych dokumentów USA za pośrednictwem portalu internetowego WikiLeaks przez najbardziej poczytne tytuły prasy amerykańskiej oraz europejskiej (m.in. przez „New York Times”, „Guardian”, „Le Monde”, „El Pais” oraz „Der Spiegel”). Ujawnione elektroniczne wersje dokumentów w głównej mierze (w pierwszej odsłonie) dotyczyły bieżących kwestii, będących przedmiotem zainteresowania amerykańskiej dyplomacji. Materiały, którym za pośrednictwem środków masowego przekazu nadano globalny wymiar, miały być tzw. bombą informacyjną podważającą wiarygodność administracji USA. Według opinii publicystów i komentatorów międzynarodowych, opublikowane dokumenty powinny rzucić nowe światło na amerykańskie relacje z sojusznikami oraz sposoby realizacji interesów w działaniach dyplomatycznych w różnych regionach globu. Dla właścicieli tzw. przeciekowego portalu internetowego publikacja tych materiałów oznaczała sukces komercyjny, który może wpłynąć na zwiększenie prawdopodobieństwa kolejnych takich akcji w przyszłości. Należy podkreślić, iż ten bezprecedensowy „przeciek” z 28 listopada 2010 roku objął 200 z 251287 dokumentów ${ }^{1}$. Odnośnie ujawnienia tzw. niewygodnych dla administracji amerykańskiej dokumentów głos zabrał nawet prezydent USA Husajn B. Obama, a także wielu wysokich rangą urzędników amerykańskich. Do sprawy ustosunkowała się także w lakonicznej formie część przywódców lub przedstawicieli odpowiednich resortów państw, których urzędnicy bądź przywódcy byli przedmiotem lub podmiotem zamieszczonych informacji ${ }^{2}$.

1 Spośród dokumentów żaden nie jest oznaczony klauzulą „ściśle tajne”, ok. 15 tys. to dokumenty „tajne”, ok. 100 tys. ,poufne” a 130 tys. nie zostało sklasyfikowanych. Szerzej: Secret US Embassy Cables, http://213.251.145.96/cablegate.html (18.12.2010).

2 Barack Obama comments on Wikileaks documents, http://www.bbc.co.uk/news/world-us-canada-10783842 (17.11.2010). 
Interpretując tę nietypową sytuację, opierając się na analogii oraz można postawić trzy arbitralne i ogólne hipotezy. W myśl pierwszej, w wyniku przestępstwa doszło do ujawnienia tajnych i poufnych dokumentów administracji amerykańskiej przez wrogo nastawione osoby działające osobno bądź w zmowie, które współpracowały dla różnorakich korzyści z podmiotami nieprzychylnymi USA. Zgodnie z drugą hipotezą, część z 251287 wykradzionych dokumentów USA jest wynikiem przestępstwa, natomiast pozostałe zostały celowo ujawnione przez administrację USA, aby osłabić za pomocą dezinformacji wydźwięk tych pierwszych. W trzecim wariancie można założyć, iż publikacja dokumentów jest celowym działaniem administracji H. B. Obamy, która za pomocą dezinformacji i manipulacji chce skierować uwagę opinii publicznej na inne kwestie, niż prowadzona od kilku miesięcy, bez większych sukcesów decydująca ofensywa w Afganistanie, która miała stać się punktem zwrotnym i zadecydować o skuteczności algorytmu funkcjonującego w stosunkach międzynarodowych pod nazwą ,globalnej wojny z terroryzmem” (ang. Global War of Terrorism - GWOT) ${ }^{3}$.

Prawdziwość pierwszej hipotezy może świadczyć o słabości amerykańskiego systemu bezpieczeństwa $\mathrm{w}$ dziedzinie obiegu dokumentów elektronicznych i jest pierwszym tak poważnym kryzysem bezpieczeństwa USA od zamachów z 11 września 2001 roku. W drugim przypadku mamy do czynienia z próbą tzw. ucieczki do przodu, która ma uchronić wybrane agencje amerykańskie od kompromitacji powodowanej nieszczelnością systemu dystrybucji poufnych i tajnych informacji między Departamentem Stanu a ambasadami amerykańskimi. W tej sytuacji, aby uniknąć impasu dyplomatycznego z podmiotami, których dotyczą „niewygodne” informacje amerykańscy specjaliści od public relations (PR) starają się dezinformując podważyć wiarygodność wykradzionych dokumentów w wyniku przestępstwa, przez wytworzenie szumu informacyjnego dzięki publikacji materiałów z oczywistymi tezami lub różnego rodzaju pomówieniami ad persona, które paradoksalnie mogą świadczyć, nie przeciw dyplomatom USA, ale dyskredytować wiarygodność portalu internetowego i autentyczność źródła przecieków. Dzięki takiemu zabiegowi strona amerykańska może ukryć istotne informacje, które mogą być niebezpieczne w rękach jej adwersarzy.

W ostatnim wariancie informacje opublikowane przez portal (którego wiarygodność jest co najmniej dyskusyjna) mogą być elementem prowadzonej GWOT, ponieważ arkana sztuki wojennej przewidują działania w wielu wymiarach, również w wymiarze psychologicznym, a opublikowane informacje mogą być narzędziem dezinformacji lub manipulacji, za pomocą której można modyfikować postrzeganie danej sprawy przez opinię publiczną, uzyskując tym samym tak pożądaną przez polityków w realiach demokracji legitymizację społeczną w celu kontynuowania tzw. polityki odpowiedzi. Z drugiej strony jednak należy pamiętać, że ujawniona do grudnia 2010 roku treść obejmuje dość niestosowne komentarze lub spostrzeżenia ad persona oraz tezy, które dla specjalistów nie są czymś niebywałym i zaskakującym tylko logicznym rozwinięciem pewnych spraw szeroko komentowanych przez publicystów, ekspertów,

3 W ujęciu behawioralnym GWOT można zdefiniować, jako: strategiczny algorytm, za pomocą którego w pierwszej dekadzie XXI wieku administracja amerykańska miała zamiar przeprowadzić system międzynarodowy z pewnego stanu początkowego do pożądanego przez nią stanu końcowego. 
naukowców lub polityków. Opublikowane informacje nie przedstawiają unikatowych treści, które mogłyby w dalszej perspektywie wpłynąć na działania dyplomacji amerykańskiej. Przykładem mogą być choćby fragmenty depesz dotyczących relacji między władzami polskimi a USA, szczególnie te odnoszące się do negocjacji warunków budowy tarczy antyrakietowej lub oceny przez urzędników i wojskowych USA wagi zaangażowania polskiego kontyngentu w Afganistanie. W jednej, jak i drugiej sprawie nie ma powodów do wzajemnych oskarżeń, manifestowania niechęci czy wywoływania impasu we wzajemnych relacjach. Ujawnione informacje moga, co najwyżej zweryfikować poglądy osób, które w dobrej wierze zakładały, iż w stosunkach między państwami to wartości implikują interesy, a nie odwrotnie. Część obserwatorów, publicystów czy ekspertów stwierdzi, iż taka, gra” nie mogłaby być prowadzona z udziałem polityków amerykańskich na tak wysokim szczeblu i nie jest kolejnym algorytmem (obok GWOT i projektu tzw. tarczy antyrakietowej), który władze USA mogą stosować do modyfikacji systemu stosunków międzynarodowych w pożądanym przez siebie kierunku. Należy mieć jednak na uwadze, iż w pierwszej dekadzie XXI wieku w zakresie posługiwania się informacjami można było zaobserwować tendencję do stosowania dezinformacji przez administrację amerykańską w celu uzyskania taktycznej, bądź strategicznej przewagi nad innymi podmiotami środowiska międzynarodowego 4 . Metoda ta była użyta w kwestii tak ważnej, jak rozpoczęcie GWOT i mogła posłużyć w tworzeniu casus belli. Aby uwiarygodnić tę hipotezę należy przytoczyć wypowiedzi George W. Busha z 2001 roku, który pod pretekstem polityki ,odpowiedzi” wdrożył algorytm GWOT, rozpoczynając inwazję na Afganistan. Po raz drugi mechanizm ten został uruchomiony w 2003 roku podczas interwencji w Iraku. Tym razem usprawiedliwieniem uderzenia militarnego stały się m.in.: pobudki humanitarne, poszukiwanie broni masowego rażenia (której ostatecznie nie znaleziono) oraz zdobycie informacji o powiązaniach irackiego reżimu z Al-Kaidą i innymi organizacjami terrorystycznymi (czego również nie udowodniono) $)^{5}$. Następnie wbrew oficjalnym deklaracjom prezy-

${ }^{4}$ Klasycznym przykładem tego typu algorytmu stosowanego wcześniej była koncepcja administracji R. Reagana dotycząca rozwoju programu tzw. gwiezdnych wojen, który stał się przykładem dobitnego sukcesu propagandy wymierzonej w głównego wówczas rywala USA w środowisku międzynarodowym, czyli ZSRR. Podobne zabiegi stosowała administracja amerykańska po awarii elektrowni jądrowej w Czarnobylu, której wyolbrzymione skutki w mediach zachodnich miały ostatecznie w opinii społeczeństw zachodnich zdyskredytować skuteczność systemu radzieckiego.

5 Według deklaracji ówczesnego sekretarza obrony USA Donalda Rumsfelda najważniejszymi celami ataku były: znalezienie i eliminacja broni masowego rażenia oraz baz terrorystów, zdobycie informacji na temat powiązań międzynarodowych organizacji terrorystycznych, zakończenie sankcji ekonomicznych nałożonych na Irak i dostarczenie do tego państwa pomocy humanitarnej, zrealizowanie rezolucji RB ONZ nr 1205 z 1999 roku oraz nr 1441 z 2002 roku, likwidacja reżimu Saddama Husajna, pomoc w ustanowieniu demokracji w Iraku, zabezpieczenie pól naftowych Iraku i innych zasobów naturalnych tego państwa. Przeciwnicy inwazji na Irak wymieniali powody takie, jak: chęć przejęcia kontroli nad irackimi rezerwami ropy naftowej i gazu ziemnego (drugie po Arabii Saudyjskiej złoża na Bliskim Wschodzie), by utrzymać monopol dolara na rynku paliwowym (Irak rozliczał swoje kontrakty w euro, ze względu na kierunek eksportu), zablokowanie wzrostu cen paliw na świecie, powiększenie dopływu środków finansowych do sektora militarno-zbrojeniowego USA, wzmocnienie „wojennej” popularności prezydenta G. W. Busha, która zapobiega obarczaniu go winą za atak terrorystyczny na Nowy Jork, zadość uczynienie żądaniom lobby izraelskiego, eliminacja nieprzychylnego Izraelowi rządu (w regionie pozostają już tylko Syria i Iran), kontynuacja strategicznego okrążania Iranu. 
denta USA okazało się, iż w więzieniu w Guantanamo stosuje się niekonwencjonalne środki przesłuchań (tortury) i przetrzymuje osoby bez wyroku sądowego (pojmane w Iraku bądź Afganistanie i oskarżone o terroryzm) oraz wbrew zasadom prawa międzynarodowego w czasie międzylądowań amerykańskich samolotów na terytorium Polski i Rumunii (członków UE) najprawdopodobniej torturowano więźniów ujętych w Afganistanie.

W spekulacjach, na potrzeby czysto akademickich rozważań można iść o krok dalej. Wiele pytań implikuje rola portalu WikiLeaks w przebiegu tzw. jaśminowej ${ }^{6}$ rewolucji w części państw Afryki Północnej i Bliskiego Wschodu ${ }^{7}$. W tym przypadku przy braku jakichkolwiek materialnych dowodów, być może zbytnią ekstrawagancją byłaby hipoteza, iż te rewolucje są skorelowane w czasie z finalną częścią wojskowej operacji w Afganistanie (poprzedzająca tzw. zwycięski odwrót) i mogą być paradoksalnie ostatnią fazą $\mathrm{GWOT}^{8}$, która z gór Afganistanu przeniosła się na ulice arabskich metropolii, stanowiąc element wojny informacyjno-psychologicznej prowadzonej sprawdzonymi metodami w nowej aranżacji. W tym ujęciu paradoksalnie tzw. niepokorny portal internetowy, który wydaje się poza jakąkolwiek kontrolą rządu USA byłby jeszcze lepszą bronią propagandową, niż swego czasu sieć radia Wolna Europa.

Biorąc pod uwagę zaprezentowane hipotezy dotyczące wiarygodności i okoliczności publikowania „przecieków” przez portal WikiLeaks i uwzględniając brak niezbitych dowodów tego zdarzenia można zadać pytania o inne dużo ważniejsze problemy, które nie zostały nagłośnione $\mathrm{w}$ globalnych środkach masowego przekazu, a wbrew politycznym deklaracjom wpływały na zakres i tempo rozwoju relacji transatlantyckich w ostatniej dekadzie.

We współpracy między Stanami Zjednoczonymi i Unią Europejską w zwalczaniu terroryzmu, do spraw które wywoływały największe napięcia można zaliczyć:

- porozumienie w sprawie PNR (ang. Personal Name Records);

- porozumienie SWIFT (ang. Society for Worldwide Interbank Financial Telecommunications);

- umowę o ekstradycji;

- umowę o wzajemnej pomocy prawnej (tzw. Mutual Legal Assistance - MLA);

- spór o umieszczanie na pokładach samolotów uzbrojonych strażników powietrznych (tzw. air marshals) na liniach transatlantyckich;

- Amerykański Program Rezygnacji z Wiz (ang. Visa Waiver Program);

- budowę w ramach UE własnego systemu nawigacji satelitarnej (pozycjonowania - GALILEO);

${ }^{6}$ Zwana również rewolucją facebookową, od nazwy jednego z największych serwisów społecznościowych.

7 Maroko, Libia, Algieria, Tunezja, Egipt, Jordania, Syria, Jemen i Bahrajn.

8 Niepokoje społeczne i wystąienia antyrządowe skierowane przeciw autorytarnym rządom, spotkały się z selektywnym poparciem państw Zachodu, ponieważ tam gdzie możliwe jest zastapienie modelu autorytarnych rządów przez system demokratyczny państwa UE i USA wyrażają powściągliwe zadowolenie, natomiast w przypadku, kiedy po obaleniu autorytarnego reżimu łamiącego od wielu dziesięcioleci prawa człowieka i podstawowe wolności mogłyby w demokratycznych wyborach zwyciężyć ugrupowania islamistów państwa Zachodu zachowują bierność, która jest dorozumianą akceptacją zbrodni dokonywanych na własnym narodzie przez rządzących satrapów (np. Libia). 
- publikowanie list grup i osób podejrzanych o terroryzm oraz finansowanie terroryzmu przez Departament Stanu USA i wyspecjalizowane struktury UE (kwestia Hamasu i Hezbollahu);

- zarzuty wobec USA o naruszenia prawa międzynarodowego w wojnie z terroryzmem przez stosowanie tortur i innego niehumanitarnego traktowania i karania;

- odmienne stanowiska wobec przyjmowania nowych rozwiązań prawnych dotyczących zwalczania terroryzmu.

Od 2001 roku przedstawiciele USA i UE w ramach prowadzonego dialogu zobowiązali się do tworzenia baz danych, do których miałyby dostęp wyspecjalizowane służby obu stron. W pierwszej kolejności owocem pracy połączonych zespołów stały się porozumienia z 6 grudnia 2001 roku, które obejmowały wymianę informacji wywiadowczych między Prokuraturą USA a Europolem. Chodziło o wskazywanie osób podejrzanych o terroryzm, potencjalnych zagrożeń i ryzyka nowych zamachów ${ }^{9}$. Równocześnie zmierzano do stworzenia skutecznej prawnej platformy wymiany tzw. danych osobowych ${ }^{10}$. Dane PNR to informacje podawane przez pasażerów i gromadzone przez linie lotnicze w celu przeprowadzenia rezerwacji oraz odprawy. Stanowią one rejestr informacji wymaganych dla rezerwacji i kontroli odlotów, a dotyczących każdego pasażera. System zawiera m.in. informacje na temat daty i trasy podróży, dane kontaktowe (adres, numer telefonu), informacje o biurze podróży i płatnościach, informacje o bagażu. Dane PNR są unikalne, jeśli chodzi o ich charakter i wykorzystanie ${ }^{11} \mathrm{w}$ przeciwieństwie do API $^{12}$ (ang. Application Programming Interface). Dane PNR wyko-

9 Porozumienie to zostało uzupełnione specjalnym suplementem 20 grudnia 2002 roku. Patrz: Supplement Agreement Between The Europol Police Office and The United States of America on The Exchange of Personal Data and Related Information, http://www.europol.europa.eu/legal/agreements/Agreements/16268-1.pdf (10.5.2010).

10 Porozumienie pomiędzy Wspólnota Europejskq a Stanami Zjednoczonymi Ameryki w sprawie przetwarzania i przekazywania danych dot. nazwy rekordu pasażera (PNR) przez przewoźników lotniczych do Departamentu Bezpieczeństwa Wewnętrznego Stanów Zjednoczonych, Biura Cet i Ochrony Granic, http://eur-lex.europa.eu/LexUriServ/LexUriServ.do?uri=OJ:L:2004:183:0083:0083:PL:PDF (12.6.2010).

${ }^{11}$ Można z nich korzystać: 1) wstecznie (dane historyczne), w tzw. postępowaniu przygotowawczym i sądowym. Informacje te ułatwiają organom ścigania podjęcie działań operacyjnych, ponieważ magazynowane przez długi czas umożliwiają prześledzenie interesujących je działań danego podmiotu; 2) w czasie rzeczywistym (dane aktualne) w celu zapobiegania przestępstwom, kontroli lub zatrzymywania osób przed popełnieniem przestępstwa, w związku z jego popełnieniem lub w trakcie jego podejmowania. W takich przypadkach dane PNR są niezbędne do analizy wcześniej ustalonych, opartych na informacjach faktycznych wskaźników ryzyka; 3) w tworzeniu modeli aktywnych wykorzystywanych do analizowania tendencji oraz opartych na informacjach faktycznych, modeli podróży i ogólnego zachowania. Szerzej: Rada Unii Europejskiej, Bruksela, 22 września 2010, (24.09) (OR. en), 13954/10, http://www.ulc.gov.pl/index.php?option=com_content\&task=view\&id=1180, (18.10.2010).

12 Dane API to biograficzne informacje pobrane z części paszportu możliwej do automatycznego odczytu i obejmujące imię i nazwisko, miejsce zamieszkania, miejsce urodzenia i obywatelstwo osoby. Zgodnie z dyrektywą o API, organy kontroli granicznej udostępniają te dane wyłącznie w przypadku lotów przybywających na terytorium UE w celu poprawy kontroli granicznej oraz zwalczania nielegalnej imigracji. Dyrektywa zezwala wprawdzie na wykorzystanie tych danych do celów egzekwowania prawa, możliwość ta została jednak pomyślana raczej, jako wyjątek niż reguła. Państwa członkowskie przechowują dane API przez 24 godziny. Dane API wykorzystywane są głównie do 
rzystywane są $\mathrm{m}$.in. do oceny ryzyka związanego z pasażerami oraz identyfikacji osób, które mogą być potencjalnie podmiotem zainteresowania organów ścigania, ale dotąd nie były o nic podejrzewane. Chodzi także o identyfikację osób, do których można przyporządkować konkretne adresy, karty kredytowe itp. związane z popełnieniem przestępstwa ${ }^{13}$.

Zawarte porozumienia z powodów formalno-prawnych stały się przedmiotem sporów. W finalizacji odpowiednich ustaleń wystąpił zasadniczy problem dotyczący zabezpieczenia wymiany danych osobowych $w$ ramach wskazanych powyżej porozumień ${ }^{14}$. Procedury amerykańskie, szczególnie dotyczące wymiany informacji PNR nie spełniają wymogów stawianych przez prawo europejskie, a dotyczących ochrony podstawowych praw człowieka i obywatela. Europejski system ochrony danych osobowych ${ }^{15}$ zakładał, iż wysyłanie informacji w ramach PNR może odbywać się tylko i wyłącznie w ramach zbliżonych systemów prawnych ${ }^{16}$. Pewnym odstępstwem od tych zakazów mogły jedynie być sprawy case-by-case, gdy istniały uzasadnione dowody w prowadzonych śledztwach. Natomiast władze Stanów Zjednoczonych po zamachach z 11 września 2001 roku rozpoczęły starania mające doprowadzić do stworzenia baz danych, które

sprawdzania tożsamości w ramach kontroli granicznej oraz zarządzania granicami, chociaż w niektórych przypadkach danymi tymi posługują się także organy ścigania w celu identyfikacji podejrzanych i osób poszukiwanych. Dane te są zatem wykorzystywane w pierwszej kolejności, jako narzędzie zarządzania tożsamością. Analiza takich danych staje się coraz bardziej powszechna na całym świecie - ponad 30 państw systematycznie z nich korzysta, podczas gdy dalsze 40 jest w trakcie tworzenia systemów API. Niektóre państwa wymagają od przewoźników, by oprócz danych API przekazywali dane PNR. Dane te wykorzystywane są w walce $\mathrm{z}$ terroryzmem oraz innymi poważnymi przestępstwami, takimi jak handel ludźmi oraz narkotykami. PNR są używane od blisko 60 lat, głównie przez organy celne, lecz także organy ścigania. Jeszcze do niedawna nie było technicznej możliwości uzyskiwania dostępu do takich danych elektronicznie i z wyprzedzeniem, dlatego też ich wykorzystywanie ograniczało się do ręcznego przetwarzania w przypadku niektórych lotów. Postęp technologiczny umożliwił elektroniczne przesyłanie danych. Szerzej: Dyrektywa Rady 2004/82/WE z 29 sierpnia 2004 roku w sprawie zobowiązania przewoźników do przekazywania danych pasażerów. Opinia nr 9/2006 dotyczqca wdrożenia dyrektywy 2004/82/WE Rady w sprawie zobowiqzania przewoźników do przekazywania z wyprzedzeniem danych pasażerów przyjęta 28 września 2006 r., http://ec.europa.eu/justice/policies/privacy/docs/wpdocs/2006/wp127_pl.pdf (18.10.2010).

13 Ibidem.

14 Szczególnie aktywni przeciwnikami nieuregulowanej dostatecznie ochrony danych osobowych w umowach podpisywanych przez przedstawicieli USA i UE byli przedstawiciele PE i grup chroniących prawa człowieka.

15 Rekomendacja Rady OECD dotycząca wymiany danych osobowych o charakterze transgranicznym z 23 września 1980 roku oraz dyrektywa 95/46/WE Parlamentu Europejskiego i Rady z 24 października 1995 roku w sprawie ochrony osób fizycznych w zakresie przetwarzania danych osobowych i swobodnego przepływu tych danych. Patrz: OECD Guidelines on the Protection of Privacy and Transborder Flows of Personal Data, http://www.oecd.org/document/18/0,2340,en_2649 34255_1815186_1_1_1_1,00.html (12.10.2010); oraz Dyrektywa 95/46/WE Parlamentu Europejskiego i Rady z 24 października 1995 r. w sprawie ochrony osób fizycznych w zakresie przetwarzania danych osobowych i swobodnego przeplywu tych danych, http://eur-lex.europa.eu/LexUriServ/ LexUriServ.do?uri=DD:13:15:31995L0046:PL:PDF (12.10. 2010).

${ }_{16}$ Dyrektywa 95/46/WE Parlamentu Europejskiego i Rady z 24 października 1995 roku w sprawie ochrony osób fizycznych $w$ zakresie przetwarzania danych osobowych i swobodnego przepływu tych danych, http://eur-lex.europa.eu/LexUriServ/LexUriServ.do?uri=DD:13:15:31995L0046:PL:PDF (12.10. 2010). 
w czasie rzeczywistym przesyłałyby informacje PNR z UE do wybranych agend administracji amerykańskiej. Po początkowej fali entuzjazmu okazało się jednak, że zarówno USA, jak i UE nie są zainteresowane zmianami legislacyjnymi, które miałyby stworzyć przyjazne okoliczności dla koherencji szczegółowych rozwiązań prawnych w dziedzinie ochrony i wymiany informacji osobowych znajdujących się w bazach PNR. Pierwszym poważnym syndromem kryzysu wokół PNR była wypowiedź komisarza Fritsa Bolkesteina ${ }^{17}$ z 16 grudnia 2003 roku, która zaowocowała komunikatem Komisji Europejskiej w sprawie ustaleń i rozmów prowadzonych między USA i UE w dziedzinie transferu danych pasażerów linii lotniczych ${ }^{18}$ oraz późniejszym listem F. Bolkesteina do Sekretarza Toma Redgea z Departamentu Bezpieczeństwa Narodowego USA ${ }^{19}$. W liście poruszono kwestię wykorzystania danych z PNR na potrzeby amerykańskiego systemu analizy danych CAPPS $\mathrm{II}^{20}$, którego funkcjonowanie zarówno w USA, jak i w UE nadal budzi wiele wątpliwości ${ }^{21}$. 28 maja 2004 roku doszło do podpisania

${ }^{17}$ EU/US talks on transfers of airline passengers ' personal data address to European Parliament Committees on Citizens' Freedoms and Rights, Justice and Home Affairs and Legal Affairs and the Internal Market Strasbourg, 16th December 2003, Speech by Commissioner Bolkestein of 16.12.2003, $\mathrm{http}$ ://europa.eu/rapid/pressReleasesAction.do?reference=SPEECH/03/613\&format=HTML\&aged= $1 \&$ language $=\mathrm{EN} \&$ guiLanguage $=\mathrm{en}(10.11 .2010)$.

18 Communication from the Commission to the Council and the Parliament of 16.12.2003, Transfer of Air Passenger Name Record (PNR) Data: A Global EU Approach, Brussels, 16.12.2003, $\operatorname{COM}(2003) 826$ final, http://eur-lex.europa.eu/LexUriServ/site/en/com/2003/com2003_0826en01.pdf (10.11.2010).

19 List do Komisarza Bolkestein do Sekretarza USA Toma Ridgea, Department of Homeland Security, 18.12.2003, http://ec.europa.eu/justice/policies/privacy/docs/adequacy/pnr/2003-12-18-letter-bolkestein_en.pdf (17.12.2010).

20 System Komputerowy Wspomagający Przeszukiwanie danych Pasażerów (ang. Computer Assisted Passenger Pre-Screening System - CAPPS II) jest programem stworzonym przez Administrację Bezpieczeństwa Transportu (Transportation Security Administration-TSA) i ma przeciwdziałać zagrożeniu terroryzmem oraz innym nie politycznym formom przestępstw. System wykorzystuje TSA do wyszukiwania informacji o danych osobach z baz komercyjnych, jak i rządowych, które mają pozwolić wytypować osoby mogące przybyć do USA drogą powietrzną lub posłużyć do zatrzymania danej osoby przez służby odpowiedzialne za bezpieczeństwo. Za pomocą trójkolorowej skali - zielonym, oznacza możliwość wejścia na pokład samolotu, żółty oznacza osobę, nad którą należy mieć szczególny nadzór na pokładzie samolotu, a czerwonym kolorem jednostki mogąc stworzyć bezpośrednie zagrożenie dla bezpieczeństwa lotu. System ten składa się z 5 modułów wyszukiwania i przekazywania danych, centralnie położonym elementem jest baza TSA i system CAPPS II, w pierwszej kolejność do systemu przekazywane są dane od linii lotniczej, w której złożona jest rezerwacja rejsu (nazwisko, adres, telefon i data urodzin), po otrzymaniu tych danych w ramach CAPPS II prośba o wyszukiwanie informacji trafia do komercjalnych baz danych, później informacje przesyłane są do CAPPS II z powrotem, następnie CAPPS II sprawdza bazy rządowe, z których informacja trafia do Sytemu, a po ostatecznym przeanalizowaniu kierowana jest do jednostek operacyjnych znajdujących się na lotniskach. Szerzej: http://www.tsa.gov/assets/pdf/Secure_Flight_PRA_Notice_9.21.04.pdf (12.05.2010).

21 W USA przeciwni programowi są przedstawiciele środowisk pozarządowych związanych z ochroną praw jednostki, ponieważ uważają oni, iż system ten służy coraz większej inwigilacji społeczeństwa przez władze federalne, dodatkowo nie gwarantuje należytego bezpieczeństwa podczas przesyłania i opracowywania danych oraz arbitralnie wyklucza spośród osób chcących dotrzeć do USA niepożądane jednostki. Szerzej: The Five Problems With CAPPS II: Why the Airline Passenger Profiling Proposal Should Be Abandoned, http://www.aclu.org/national-security/five-problems-capps-ii (5.12.2010). 
porozumienia o wymianie danych PNR między przewoźnikami lotniczymi a amerykańskim Biurem Ceł i Ochrony Granic (dalej: USA-UE PNR) ${ }^{22}$. Porozumienie to zobowiązywało europejskie linie lotnicze do dostarczenia danych w ramach PNR do władz USA na 15 minut przed startem samolotu. Zgodność porozumienia z europejskim systemem prawnym zanegowała grupa robocza Parlamentu Europejskiego, powołując się na art. $29 \mathrm{i}$ art. 30 dyrektywy 95/46/EC oraz art. 14 dyrektywy 97/66/EC. Grupa, wydając negatywną opinię o porozumieniu w konsekwencji, doprowadziła do rozpatrzenia kwestii zgodności dokumentu z prawem europejskim przez ówczesny Europejski Trybunał Sprawiedliwości ${ }^{23}$. ETS anulował decyzję Rady z 17 maja i decyzję Komisji z 14 maja 2004 roku oraz zawiesił 30 maja 2006 roku wykonywanie porozumienia USA-UE PNR ${ }^{24}$, a samą umowę pozostawiał do rewizji Radzie Europejskiej do 30 września 2006 roku $^{25} .16$ października 2006 roku Rada w tej sprawie wydała decyzję umożliwiającą wypracowanie nowego porozumienia w sprawie USA-UE PNR ${ }^{26}$, które zostało podpisane 23 lipca 2007 roku w Brukseli i 26 lipca 2007 roku w Waszyngtonie, a ostatecznie ratyfikowane w Waszyngtonie 19 października 2010 roku $^{27}$.

Problemy z przyjęciem pakietu PNR zbiegły się w czasie z uruchomieniem przez władze USA Sytemu Przylotów i Odlotów (ang. Arrival and Departure Information System - ADIS) ${ }^{28}$ oraz Automatycznego Systemu Celów (ang. Automated Target

${ }^{22}$ KE uznała, iż poziom gwarantowanych zabezpieczeń systemu wymiany danych PNR jest zgodny z dyrektywą z 1995 r. o ochronie danych osobowych. Umowa ta została wymierzona w terroryzm i najcięższe przestępstwa kryminalne o charakterze transgranicznym. Szerzej: Agreement between the European Community and the United States of America on the processing and transfer of PNR data by air carriers to the United States Department of Homeland Security, Bureau of Customs and Border Protection, Signed in Washington on 28.5.2004, http://ec.europa.eu/justice/policies/privacy/docs/adequacy/pnr/2004-05-28-agreement_en.pdf (10.12.2010).

${ }_{23}$ Opinion 8/2004 on the information for passengers concerning the transfer of PNR data on flights between the European Union and the United States of America, 11733/04/EN WP 97, 30.08.2004, http://ec.europa.eu/justice/policies/privacy/docs/wpdocs/2004/wp97_en.pdf(10.12.2010).

${ }^{24}$ Judgment of the Court of Justice in Joined Cases C-317/04 and C-318/04, European Parliament $v$ Council of the European Union and European Parliament $v$ Commission of the European Communities, PRESS RELEASE No 46/06, 30.05.2006, http://curia.europa.eu/en/actu/comuniques/cp06/aff/cp060046en.pdf (14.12.2010).

25 Według oceny ETS umowa ta nie była zgodna z m.in. zapisami Konwencji o Ochronie Praw Człowieka i Podstawowych Wolności z 1950 roku, Traktatem o Unii Europejskiej oraz dyrektywą 95/46/EC.

${ }^{26}$ Council Decision 2006/729/CFSP/JHA of 16 October 2006 on the signing, on behalf of the European Union, of an Agreement between the European Union and the United States of America on the processing and transfer of passenger name record (PNR) data by air carriers to the United States Department of Homeland Security, http://ec.europa.eu/justice/policies/privacy/docs/adequacy/pnr/2006_10_PNR_en.pdf (14.10.2010).

${ }_{27}$ Agreement between the European Union and the United States of America on the processing and transfer of passenger name record (PNR) data by air carriers to the United States Department of Homeland Security, L298/29, http://ec.europa.eu/justice/policies/privacy/docs/adequacy/pnr/2006_ 10 accord_US_en.pdf (11.12.2010).

${ }^{28}$ System ADIS (ang. Advanced Passenger Information System) miał identyfikować i autoryzować dane pochodzące z PNR i API. Ma zostać on zastapiony Systemem Zapisu Rekordów (ang. System of Record Notice - SORN). Dane z ADIS trafiają w pierwszej kolejności do takich programów, jak: System Informacji o Wymianie Gości i Studentów (ang. ICE Student and Exchange Visitor Information System - SEVIS), Serwis ds. Imigrantów i Obywateli (ang. US Citizenship and Immigration 
System $)^{29}$ pod auspicjami Departamentu Bezpieczeństwa Narodowego. Nowe rozwiązania wdrożone przez administrację amerykańską nie uzyskały aprobaty europejskich partnerów, ponieważ nie gwarantowały ochrony danych osobowych w takim samym zakresie obywatelom UE, jak USA. W tej sytuacji 13 lutego 2008 roku Jonathan Faull komisarz ds. spraw zagranicznych złożył zażalenie na umowę między USA i UE w sprawie PNR ${ }^{30}$. J. Faull powołał się na kolizję przyjętego przez USA rozwiązania z dyrektywą 96/46/EC o ochronie danych osobowych ${ }^{31}$ i ustaleniami wypracowywanymi w ramach formuły tzw. Safe Harbour (bezpieczna przystań) ${ }^{32}$. Atmosfery nie

Services - USCIS), Komputerowy System Zarządzania Aplikacjami Informacji (ang. Computer Linked Applications Information Management System - CLAIMS 3), Komponent Pasażerskich Operacji w ramach Ochorny Ceł i Granic (ang. Passenger Processing Component of the Customs and Border Protection - CBP), System Komunikacji Identyfikacji Zagrożeń (ang. Treasury Enforcement Communications System - TECS), US - VISIT IDENT. Szerzej: Fact Sheet IDENT and IAFIS Interoperability, http://www.visaserve.com/CM/Articles/US\%20VISIT\%20Fact\%20Sheet.pdf (14.05.2010) oraz Customs and Border Protection Advanced Passenger Information System Systems of Records, http://www.dhs.gov/xlibrary/assets/privacy/privacy_sorn_cbp_apis_final_rule.pdf (14.5.2010).

29 ATS to system sprzężony z ADIS i systemami wchodzącymi w skład PNR oraz API, który odpowiedzialny jest za wyszukiwanie potencjalnych osób niebezpiecznych $\mathrm{i}$ typowanie ich danych dla dalszego przetwarzania przez wyspecjalizowane systemy bezpieczeństwa służb federalnych. Ibidem.

30 R. Goldirova, Brussels attacks new US security demands, 14.02.2008, http://euobserver.com/9/25657 (16.12.2010).

31 Directive 95/46/EC of the European Parliament and of the Council of 24 October 1995 on the protection of individuals with regard to the processing of personal data and on the free movement of such data, Official Journal L 281, 23/11/1995. Uzupełniła ją decyzja Komisji z 26 lipca 2000 roku dotycząca zasad bezpieczeństwa wymiany danych z amerykańskim Departamentem Handlu (Commission Decision of 26 July 2000 pursuant to Directive 95/46/EC of the European Parliament and of the Council on the adequacy of the protection provided by the safe harbour privacy principles and related frequently asked questions issued by the US Department of Commerce, 2000/520/EC, Official Journal L 215, 25/08/2000) oraz dyrektywa w sprawie ochorny prywatności w komunikacji elektronicznej (Directive 2002/58/EC of the European Parliament and of the Council of 12 July 2002 concerning the processing of personal data and the protection of privacy in the electronic communications sector (Directive on privacy and electronic communications, Official Journal L 201, 31/07/2002).

32 Proces ten miał doprowadzić do stworzenia koherentnego systemu wymiany danych personalnych, który gwarantowałby odpowiedni akceptowalny przez obie strony zakres zasad bezpieczeństwa w ramach zarządzania i przesyłu odpowiednich rekordów, również w ramach np. korporacji transnarodowych działających w państwach UE, a mających swe centrale w USA. Według założeń podstawowych zasad przyświecających tej formule współpracy każda osoba, której dane trafiają do systemu musi być o tym poinformowana oraz mieć wiedzę jak będą te dane wykorzystywane, osoba musi mieć możliwość wycofania swoich danych zanim trafią do państwa trzeciego, transfer danych może mieć miejsce tylko do państw trzecich lub organizacji, które zagwarantują podstawowe zasady ochrony danych, użytkownicy systemu mają obowiązek zapobiegać zagubieniu przesyłanych informacji, dane muszą być zbierane w określonym celu, osoba udostępniająca swoje dane musi mieć dostęp do informacji o sobie i możliwość korekty lub ich skasowania kiedy są one nieścisłe, wszystko powinno zostać oparte na odpowiednich regulacjach prawnych. W ramach prowadzonego dialogu powstały m.in. dokumenty regulujące wymianę tzw. danych personalnych UE. Do najważniejszych należy zaliczyć: decyzję Komisji z 26 lipca 2000 roku w sprawie adekwatności ochrony przewidzianej przez zasady ochrony prywatności w ramach „,bezpiecznej przystani” oraz przez odnoszące się do nich pytania najczęściej zadawane, opublikowane przez Departament Handlu USA, http://eur-lex.europa.eu/LexUriServ/LexUriServ.do?uri=DD:16:01:32000D0520:PL:PDF (10.05.2010) a także The application of Commission Decision 520/2000/EC of 26 July 2000 pursuant to Directive 95/46 of the European Parliament and of the Council on the adequate protection of personal data provided by the Safe 
poprawiło podpisanie 12 lutego 2008 roku przez władze USA oraz przedstawicieli rządu Czech wzajemnego porozumienia o wymianie bezwizowej (MOU) ${ }^{33}$, nie uwzględniając zdania przedstawicieli UE w tej sprawie. Krok ten mógł skłonić grono decyzyjne UE do zaostrzenia stanowiska w kwestii PNR, tym bardziej, że warunkowo obowiązująca od 2007 roku umowa USA-UE PNR znajdowała się od chwili ratyfikacji w zawieszeniu - jej dalszy los zależał od woli członków Parlamentu Europejskiego, który na mocy traktatu lizbońskiego zyskał prawo zatwierdzania umów międzynarodowych zawieranych przez UE. Możliwość odrzucenia przez PE umowy o PNR tworzyła realny problem natury formalno-pranej dla transatlantyckich przewoźników lotniczych. Ostatecznie na początku maja 2010 roku PE odroczył głosowanie nad umową z 2007 roku w zamian za prezentację tzw. nowego pakietu dotyczącego rozwiązań przyjętych w ramach USA-UE PNR. Przygotowany przez Komisję Europejską tzw. nowy pakiet ma zawierać „globalną zewnętrzną strategię PNR” lub „uniwersalny model PNR", który wyznaczyłby zasady tworzenia porozumień w ramach wymiany PNR Unii Europejskiej z innymi podmiotami ${ }^{34}$. Komisja komunikat w sprawie globalnego podejścia do przekazywania danych dotyczących przelotu pasażera (PNR) państwom trzecim wydała 21 września 2010 roku $^{35}$.

Kolejną ważną sprawą, która podzieliła USA i UE w dziedzinie wspólnego zwalczania terroryzmu była właściwa ochrona danych osobowych i wolności obywatelskich w systemie SWIFT $^{36}$ oraz rola UE w amerykańskim planie kontroli i monitoringu transakcji finansowych w ramach Programu Przepływu Terrorystycznych Środków Finansowych (ang. U.S. Terrorist Finance Tracking Program - TFTP). Przedstawiciele administracji USA zapewniali, iż zbierane w tym systemie dane są wykorzystywane do zwalczania terroryzmu i przekazywane wyłącznie do Departamentu Finansów USA na wniosek sądu ${ }^{37}$. W lipcu 2007 roku doszło do konsensusu, dzięki któremu władze USA

Harbour Privacy Principles and related Frequently Asked Questions issued by the US Department of Commerce 14.02.2002, http://ec.europa.eu/justice/policies/privacy/docs/adequacy/sec-2002-196/sec-2002-196_en.pdf(10.12.2010); Commission Staff Working Document - The implementation of Commission Decision 520/2000/EC on the adequate protection of personal data provided by the Safe Harbour privacy Principles and related Frequently Asked Questions issued by the US Department of Commerce SEC(2004)1323, http://ec.europa.eu/justice/policies/privacy/docs/adequacy/sec-2004-1323_en.pdf (10.12.2010) oraz U.S. - European Union Safe Harbor, http://www.export.gov/safeharbor/eu/index.asp (17.12. 2010).

33 Inne państwa UE, które ustaliły zasady wymiany danych indywidualne poza UE to: Wielka Brytania, Estonia, RFN i Grecja, http://www.fcc.gov/pshs/docs/clearinghouse/DHS-MemorandumOfUnderstanding.pdf (12.12.2010).

34 Zgodnie z założeniami PE dotyczącymi czasu, zakresu i gwarancji bezpieczeństwa przechowywanych i transferowanych danych obywateli UE przez PNR system.

${ }^{35}$ Komunikat Komisji w sprawie globalnego podejścia do przekazywania danych dotyczacych przelotu pasażera (PNR) państwom trzecim, $\operatorname{KOM(2010)~} 492$ wersja ostateczna, Bruksela, 21.09.2010, http://www.ulc.gov.pl/index.php?option=com_content\&task=view\&id=1180 (18.12.2010).

36 Society for Worldwide Interbank Financial Telecommunications to system, którego główna siedziba znajduje się w Belgii. System ten odpowiada za łączenie wielu podmiotów za pomocą łącz elektronicznych umożliwiających tzw. potwierdzanie przelewów elektronicznych, http://www.swift.com/ (12.12.2010).

37 Dzięki dostępowi do danych SHIFT władze USA mogły kontynuować ponad 1550 wspólnych śledztw z rządami państw UE, a wiele z nich przyczyniło się do rozpoczęcia nowych śledztw wymierzonych w działające na terytorium UE grupy terrorystyczne. 
mogły posiadać dostęp do SWIFT jedynie w celach antyterrorystycznych. Napięcia wokół inwigilacji amerykańskich służb w systemie SWIFT zbiegły się w 2009 roku z procesem rekonstrukcji systemu SWIFT i redukcją liczby serwerów znajdujących się w USA, co ograniczyło przepływ dużej części danych do amerykańskiego TFTP (od tego momentu zróżnicowaniu uległ transfer danych pomiędzy europejskimi a amerykańskimi komponentami systemu). Działania te doprowadziły do nowego porozumienia między USA a UE wyrażającego zgodę na monitoring SWIFT w Europie przez służby amerykańskie współpracujące z amerykańskim Departamentem Finansów. W listopadzie 2009 roku Komisja Europejska dokonała kolejnych uzgodnień z USA dotyczących SWIFT, jednak tym razem ze względu na wejście w życie traktatu lizbońskiego kluczowe znaczenie w tej kwestii miała postawa PE. Członkowie PE po zapoznaniu się z całą sytuacją postanowili w lutym 2010 roku zawiesić współpracę z USA w tej sprawie z powodu naruszeń podstawowych praw i wolności ${ }^{38}$. Po dyskusjach na forum PE nową umowę w sprawie SWIFT odrzucono w głosowaniu stosunkiem 378 do 196. Główną przyczyną odrzucenia porozumienia był brak wystarczającego zabezpieczenia danych osobowych obywateli UE. Po odrzuceniu projektu przez PE rozpoczęto ponowne negocjacje dotyczące porozumienia SWIFT. Nowy projekt umowy powstał w maju 2010 roku. Uwzględniał dwie podstawowe kwestie, na które zwrócił uwagę PE: gwarancje prawne zapewniające ochronę danych osobowych obywateli UE znajdujących się w SWIFT i zwiększenie kontroli struktur UE nad dostępem do SWIFT amerykańskiej administracji $^{39}$. W połowie lipca 2010 roku podpisano nową umowę dotyczącą dostępu do SWIFT. Na mocy porozumienia dane obywateli UE zdobywane przez USA z wykorzystaniem systemu SWIFT podlegają ochronie administracyjnej (EUROPOL ma prawo wyrazić zgodę lub nie na transfer danych danego obywatela UE do bazy Departamenty Finansów). Pod naciskiem PE zagwarantowano również wyznaczenie przez KE niezależnego obserwatora w Waszyngtonie, który nadzoruje przepływ danych z SWIFT. W umowie zapisano również plan stworzenia przez KE równorzędnego względem amerykańskiego TFTP systemu do końca 2010 roku. Europejski odpowiednik amerykańskiego systemu ma na terytorium UE monitorować transakcje w ramach SWIFT i przesyłać wyciagi z przeanalizowanych danych do władz USA i kontrolować zakres tworzenia zbyt rozległych zadaniem europejskich parlamentarzystów baz danych w USA dotyczących obywateli UE i transakcji wykonywanych z terytoriów państw członkowskich UE. W umowie administracja USA zobowiązała się do pomocy i wspierania budowy unijnego systemu TFTP. Pomimo obaw przed sprzeciwem grupy państw UE, która nie byłaby zainteresowana budową takiego systemu ze względów finansowych, jak i oporu narodowych służb specjalnych PE 8 lipca 2010 roku podjął decyzję (stosunkiem 484 do 109 głosów przy 12 wstrzymujących się)

38 U.S. /EU Agreements on Mutual Legal Assistance and Extradition Enter into Force. U.S. Department of Justice Press Release, February 1, 2010, http://useu.usmission.gov/mlat_feb0110.html (17.12.2010).

39 MEPS Hail Historic Rejection of SWIFT Deal, „Agency Europe”, February 13, 2010; Countering Terrorist Threats-In the Air and on the Ground, „EU Insight”, April 2010; SWIFT: Commission to Negotiate under Pressure from EP, „Europolitics”, 23.04.2010, http://www.fas.org/sgp/crs/ row/RS21998.pdf (12.12.2010). 
o budowie europejskiego TFTP. Porozumienie między USA i UE w sprawie SWIFT weszło w życie 1 kwietnia 2010 roku i ma obowiązywać przez 5 lat ${ }^{40}$.

Różnice w podejściu do zasadniczych spraw ujawniły się przy negocjacjach związanych z dwiema umowami. Pierwszą była umowa dotycząca ekstradycji, drugą - umowa o wzajemnej wszechstronnej pomocy prawnej.

Oba porozumienia były negocjowane od 2001 roku z zamiarem ułatwienia kontaktów oraz współpracy UE i USA w dziedzinie prawa karnego ${ }^{41}$. Miały być również pozbawione w miarę możliwości wszelkich klauzul derogacyjnych, które utrudniałyby współpracę oraz respektować dotychczasowe bilateralne umowy ${ }^{42}$. Umowa o ekstradycji ułatwiać miała wymianę podejrzanych o najcięższe przestępstwa i zbrodnie, nie wyłączając terroryzmu oraz informacji ułatwiających współpracę prawną w tym zakresie. W dokumencie zawarto również konkretne klauzule dotyczące różnic w wymiarze stosowania kar za określone przestępstwa, szczególnie kary śmierci, która jest nadal orzekana i wykonywana w większości amerykańskich stanów. Możliwość orzeczenia przez sąd amerykański najwyższego wymiaru kary wobec podejrzanego może stanowić podstawę do odmowy wydania danej osoby do USA. Umowa o pomocy prawnej miała zwiększyć możliwość wymiany informacji o operacjach finansowych między USA a UE w sprawach dotyczących dochodzeń kryminalnych, szczególnie tych, które obejmowały przelewy międzynarodowe. W umowie przewidziano również kontynuowanie współpracy z zarządami banków w tej sprawie oraz powoływanie wspólnych zespołów dochodzeniowych, możliwości użycia wideo konferencji do przesłuchiwania świadków oraz wymiany niezbędnych informacji w toku postępowania ${ }^{43}$. Zgodnie $\mathrm{z}$ umowa, dane osobowe miały podlegać wymianie $\mathrm{z}$ dochowaniem wszelkich procedur bezpieczeństwa, które spełniałyby normy UE.

Zgodnie z decyzją Rady 2003/516/WE z 6 czerwca 2003 roku dotyczącą podpisania umów między Unią Europejską a Stanami Zjednoczonymi Ameryki w sprawie ekstradycji oraz wzajemnej pomocy prawnej w sprawach karnych ${ }^{44}, 25$ czerwca $^{2} 003$ roku

40 Jeśli w trakcie tego czasu władze UE stworzą własny system TFTP, to USA i UE mają ustalić czy funkcjonowanie tej umowy będzie dalej konieczne. Szerzej: T. Vogel, SWIFT Deal on Data Sharing with U.S. Reopened, „European Voice”, 24.06.2010; President Obama Backs Conclusion of SWIFT Agreement Between EU and US, „Agence Europe”, 25.06.2010; SWIFT: Rapporteur Announces Last-Minute Agreement, „Europolitics”, 25.06.2010; European Parliament Press Release, „Parliament Gives Green Light for SWIFT II", 8.07.2010.

41 Umowy miały harmonizować dwustronne porozumienia między USA a poszczególnymi państwami UE, ułatwiać proces ekstradycji, lepszą wymiany informacji i współpracę procesową. Przedstawiciele USA i UE mieli nadzieję, że te dwie umowy będą przydatne nie tylko w zwalczaniu terroryzmu, ale i innych sprawach dotyczących międzynarodowej przestępczości, defraudacji finansowych, handlu narkotykami i ludźmi.

42 EU/US agreements on extradition and on mutual legal assistance, Luxembourg, 23 October 2009 14826/09 (Presse 303), http:/www.consilium.europa.eu/uedocs/cms_data/docs/pressdata/en/jha/110727.pdf (16.12.2010).

${ }_{43}$ Porozumienie dotyczące MLA umożliwiło również administracji USA dostęp do europejskich rachunków bankowych i finansowych informacji w sprawach dochodzeń kryminalnych, wykorzystanie procedur z MLA miało pozwolić na wideo konferencje, w których mieli uczestniczyć przedstawiciele władz USA i UE we wspólnych dochodzeniach.

44 Decyzja Rady z 6 czerwca 2003 roku dotyczaca podpisania Umów między Unia Europejska a Stanami Zjednoczonymi Ameryki w sprawie ekstradycji oraz wzajemnej pomocy prawnej w sprawach karnych (2003/516/WE), Dz. U. L 181, 19.07.2003. 
w imieniu Unii Europejskiej podpisano Umowę o ekstradycji między Unią Europejską a Stanami Zjednoczonymi Ameryki ${ }^{45}$ i Umowę o wzajemnej pomocy prawnej między Unią Europejską a Stanami Zjednoczonymi Ameryki (tzw. Mutual Legal Assistance - MLA $)^{46}$. Dodatkowo w 2008 roku uzgodniono nowe porozumienie między UE a USA o ekstradycji ${ }^{47}$ będące sprostowaniem do umowy podpisanej 25 czerwca 2003 roku, ponieważ pierwsza umowa nie została zaakceptowana przez wszystkie zainteresowane strony. 30 listopada 2009 roku podjęta została decyzja Rady 2009/933/WPZiB w sprawie rozszerzenia, zakresu terytorialnego umowy o ekstradycji między UE a USA. Zgodnie z decyzją Rady 2009/820/WPZiB z 23 października 2009 roku zawarto nową Umowę o ekstradycji między Unią Europejską a Stanami Zjednoczonymi Ameryki oraz Umowę o wzajemnej pomocy prawnej między Unią Europejską a Stanami Zjednoczonymi Ameryki. Umowy weszły w życie 1 lutego 2010 roku $^{48}$.

Trwające ponad 9 lat negocjacje i procedury ratyfikacji powodowały, iż przeciwnicy tych umów zarzucali ich inicjatorom dublowanie istniejących już rozwiązań dwustronnych i psucie relacji między FBI i CIA oraz innymi amerykańskimi wyspecjalizowanymi organami a policjami narodowymi i służbami specjalnymi poszczególnych państw EU. Krytykowano zakres kompetencji Europolu, którego dostęp do informacji wywiadowczych zależy od dobrej woli służby specjalnych poszczególnych państw UE. Z drugiej strony, Europejczycy zarzucali Amerykanom, iż żądają informacji, a nie chcą udostępnić własnych. Dodatkowo wytykano stronie amerykańskiej utrzymanie kary śmierci i sprzeciw władz USA do wydawania własnych obywateli, nawet w sprawach dotyczących terroryzmu.

Kolejną kwestią, która ujawniła poważne różnice zdań była ochrona lotów transatlantyckich między państwami UE a USA ${ }^{49}$, która w 2009 roku stała się jednym z kluczowych problemów, po nieudanej próbie porwania samolotu lecącego z Amsterdamu do Detroit $^{50}$. W wyniku prowadzonych rozmów 21 stycznia 2010 roku doszło do podpi-

45 Agreement on extradition between the European Union and the United States of America, Dz. U. L181/27, 19.07.2003.

${ }^{46}$ EU-US Summit, Washington, 25 June 2003, Brussels, 23.06.2003, http://trade.ec.europa.eu/doclib/docs/2003/november/tradoc_114831.pdf (13.12.2010).

47 Dz. U. UE L 193/20, 22.07.2008.

48 W lutym 2010 roku połączone zespoły USA i UE stworzyły procedury dotyczące ekstradycji i wszechstronnej prawnej pomocy tzw. MLA. Szerzej: EU/US agreements on extradition and on mutual legal assistance, http://www.consilium.europa.eu/uedocs/cms_data/docs/pressdata/en/jha/110727.pdf (10.12.2010).

4916 grudnia 2002 roku KE przesłała projekt rozporządzenia (KE) Nr 2320/2002 do PE i Rady Europejskiej ustanawiający wspólne zasady ochrony lotnictwa cywilnego w ramach UE. Projekt ten został zastapiony 11 marca 2008 roku (po konsultacjach w PE i Radzie) przez nową Propozycję Rozporządzenia (KE) Nr 300/2008, której postanowienia zaczęły obowiązywać od 29 kwietnia 2009 roku.

${ }_{50} \mathrm{~W}$ międzyczasie przyjmowano dokumenty uzupełniające prawodawstwo UE w zakresie ochrony lotów, np.: rozporządzenie nr 272/2009 z 2 kwietnia 2009 roku uzupełniające wspólne podstawowe normy ochrony lotnictwa cywilnego określone w załączniku do rozporządzenia (WE) 300/2008 Parlamentu Europejskiego i Rady; rozporządzenie nr 297/2010 z 9 kwietnia 2010 roku zmieniające rozporządzenie (WE) nr 272/2009 uzupełniające wspólne podstawowe normy ochrony lotnictwa cywilnego; rozporządzenie nr 1254/2009 z 18 grudnia 2009 roku ustanawiające kryteria pozwalające państwom członkowskim na odstępstwo od wspólnych podstawowych norm ochrony lotnictwa cywilnego i przyjęcie alternatywnych środków w zakresie ochrony; rozporządzenie nr 18/2010 
sania wspólnej deklaracji o ściślejszej współpracy między USA i UE w ochronie lotów i propagowaniu rozwiązań prawnych i technicznych w tym zakresie w wymiarze globalnym $^{51}$. Dokument ten spowodował „burzę” w PE, ponieważ w jednym z punktów umieszczono zapis o rozlokowaniu na lotniskach specjalnych skanerów przeznaczonych do sprawdzania osób, które przechodzą kontrolę bezpieczeństwa przed udaniem się na pokład samolotu. Przeciwko takiemu rozwiązaniu wystąpiło kilku europosłów, którzy obawiali się, iż tego typu urządzenia będą naruszały prawa i wolności obywatelskie oraz mogą stanowić zagrożenie dla zdrowia. 15 czerwca 2010 roku w tej sprawie KE skierowała specjalny Komunikat do PE i Rady dotyczący użycia skanerów bezpieczeństwa na lotniskach $\mathrm{UE}^{52}$. Poruszenie w kwestii skanerów na lotniskach wznieciło również na nowo dyskusję między USA i UE o potrzebie przebywania na pokładach samolotów uzbrojonych strażników powietrznych tzw. air marshals ${ }^{53}$.

Następną sprawą wywołującą spory, a dotykającą również zagadnień związanych ze zwalczaniem terroryzmu jest amerykański Program Rezygnacji z Wiz (ang. Visa Waiver Program - VWP), który nie obejmuje wszystkich państw członkowskich UE. Problem dotyczy tzw. nowych państw członkowskich, w tym także Polski, której władze bezskutecznie apelują do amerykańskiego Kongresu o zmianę rygorystycznego prawa wizowego. Impas $\mathrm{w}$ tej kwestii bezskutecznie próbowali przełamać w lipcu 2007 roku kongresmeni USA przesyłając rekomendacje implementacyjne, w myśl których program VWP ma m.in. objać większą ilość państw UE. Do innych ważnych postulatów rekomendacji można zaliczyć: zmiany standardów bezpieczeństwa dotyczące paszportów - dane biometryczne oraz lepszą wymianę informacji ${ }^{54}$. W rezultacie działań administracja amerykańska zobowiązała się kontynuować dialog polityczny w tej sprawie z pozostałymi członkami UE, czyli Bułgarią, Cyprem, Rumunią i Polską.

Kolejnym punktem spornym stało się publikowanie oficjalnych list zawierających organizacje i osoby podejrzane o terroryzm oraz finansowanie terroryzmu. Pierwszoplanowym problemem była klasyfikacja Hezbollahu. Według USA organizacja ta jest odpowiedzialna za wspieranie terroryzmu. Dodatkowo zdaniem amerykańskiej administracji umieszczenie tej organizacji na liście Departamentu Stanu powinno wpłynąć obligatoryjne na zamrożenie aktywów Hezbollahu w Europie. Przedstawiciele UE

z 8 stycznia 2010 roku zmieniające rozporządzenie Parlamentu Europejskiego i Rady (WE) nr 300/2008 w zakresie specyfikacji dla państwowych programów kontroli jakości w dziedzinie ochrony lotnictwa cywilnego. W procesie implementacji pozostają: rozporządzenie nr 72/2010 z 26 stycznia 2010 roku ustanawiające procedury przeprowadzania inspekcji Komisji w zakresie ochrony lotnictwa oraz rozporządzenie nr 185/2010 z 4 marca 2010 roku ustanawiające szczegółowe środki w celu wprowadzenia w życie wspólnych podstawowych norm ochrony lotnictwa cywilnego.

51 U.S.-EU Joint Declaration on Aviation Security, http://www.dhs.gov/ynews/releases/pr_1264119013710.shtm (12.12.2010).

52 Communication from the Commission to the European Parliament and the Council on the Use of Security Scanners at EU airports, $\operatorname{COM}(2010) 311$ final, http://ec.europa.eu/transport/air/security/doc/com2010_311_security_scanners_en.pdf (13.12.2010).

53 U.S. Conciliatory in Air Marshal Demands, Associated Press, 26.04.2004; J. M. Doyle, U.S., EU To Trade Information on Sensors, MANPADS Defense, Homeland Security and Defense, 24.11.2004.

54 A. Siskin, Visa Waiver Program, „CRS Report”, RL32221, http://www.ilw.com/immigrationdaily/news/2007,0314-crs1.pdf (16.12.2010). 
natomiast chcieliby uznać podmiotowość Hezbollahu. Ich zdaniem umieszczenie Hezbollahu na liście europejskich organizacji terrorystycznych niekorzystnie wpłynęłoby na stosunki z Libanem i sytuację w regionie. Przywódcy UE uważają iż libański Hezbollah posiada legitymizację społeczną $\mathrm{i}$ jest cennym partnerem w przełamaniu impasu na Bliskim Wschodzie. Kwestia Hezbollahu przypomina również wcześniejsze kontrowersje dotyczące Hamasu, który władze USA wbrew opinii przedstawicieli UE umieściły na liście organizacji podejrzewanych o terroryzm, tworzonej przez Departament Stanu USA.

Ważnym elementem, który może świadczyć o ograniczonym wzajemnym zaufaniu w kwestiach bezpieczeństwa (a co za tym idzie również w dziedzinie zwalczania terroryzmu) pozostaje sprawa budowy w ramach UE własnego systemu nawigacji satelitarnej. Pomimo porozumienia podpisanego 26 czerwca 2004 roku o systemach nawigacji satelitarnej europejskim GALILEO i amerykańskim GPS, co do właściwych intencji stron w tej sprawie można mieć poważne wątpliwości, co najmniej z dwóch powodów. Pierwszym był przedłużający się okres negocjowania porozumienia (prace trwały ponad 4 lata) zakładającego techniczną współpracę przy rozszerzaniu zasięgu dwóch równoległych, lecz kompatybilnych systemów pozycjonowania współpracujących ze sobą podmiotów. W zamyśle pomysłodawców GALILEO powinien stać się otwartym systemem o zasięgu światowym, a użytkownicy GPS za pomocą swoich odbiorników/nadajników mogliby w tym samym czasie korzystać z dwóch systemów ${ }^{55}$. Drugą sprawą jest chęć uniezależnienia się UE od wpływu administracji USA kontrolującej system GPS (systemem ten został stworzonym przez amerykańskie siły zbrojne). Należy zaznaczyć, iż pomysł powstania GALILEO narodził się w latach osiemdziesiątych XX wieku, a najprawdopodobniej główną przyczyną był brak zaufania do istniejących systemów, które mogły być w każdej chwili wyłączone lub zakłócone przez ich właściciela Departament Obrony USA oraz celowo ograniczona dokładność tego systemu dla użytkowników spoza amerykańskiej administracji ${ }^{56}$. Pomimo zapowiedzi przedstawicieli UE, iż system GALILEO jest typowo komercyjnym przedsięwzięciem, nie trudno domyślić się, iż może mieć szersze zastosowanie i być pomocnym narzędziem w prowadzeniu samodzielnych operacji wywiadowczych przez wyspecjalizowane organy UE. Dziwić mogą i źle świadczyć o wiarygodności UE nieustanne opóźnienia w budowie GALILEO ${ }^{57}$.

55 Potencjalny rynek tego systemu: potrzebny sprzęt do eksploatacji koszt 3 mld euro, szacowane dochody są rzędu $250 \mathrm{mld}$ w skali roku, po uruchomieniu ma stworzyć ok. 150 tys. miejsc pracy. Do obsługi sytemu wykorzystane zostanie ok. 24 satelitów oraz stacje naziemne, szerzej w: ibidem.

56 Należy zaznaczyć, iż swój pierwszy systemem nawigacji satelitarnej pod nazwą CYKADA uruchomiło w 1967 roku Ministerstwo Obrony ZSRR, jednak ze względu na realia zimnej wojny o współpracy w zakresie wykorzystania przez Wspólnoty Europejskie radzieckiego systemu nie mogło być mowy, podobnie jest w pierwszej dekadzie XXI w. pomimo kolejnej mutacji systemu Federacji Rosyjskiej obie strony UE i władze FR nie prowadzą oficjalne żadnych rozmów w tym zakresie.

57 Faza definicji systemu przypadła w latach 1999-2000. W 2002 roku rozpoczęto fazę wdrażania (pierwszy, naziemny etap testów zakończono w 2004 r., w drugi rozpoczął się w 2005 roku wystrzeleniem satelity GIOVE-A), natomiast oddanie do użytku miało nastąpić w 2008 roku. W 2007 roku wystąpiły opóźnienia wywołane kosztami i datę uruchomienia systemu przełożono na 2012 rok, jednak w 2009 roku sposób zarządzania budową systemu i jego wdrażanie zostały zanegowane przez Europejski Trybunał Obrachunkowy. W tym samym roku z powodów finansowych zredukowano części 
Wkrótce po rozpoczęciu tzw. wojny z terroryzmem kluczową sprawą stał się również status osób schwytanych na terytorium Afganistanu i podejrzanych o terroryzm. Dodatkowo sytuację prawną amerykańskich więźniów komplikowało osadzenie w więzieniu stworzonym w bazie wojskowej w Guantanamo na Kubie bez wyroku sądu, wyłącznie na podstawie decyzji wojskowej komisji. Problemem o wymiarze międzynarodowym stały się również warunki, w jakich administracja USA od 2001 roku przetrzymuje więźniów oraz potwierdzone w zeznaniach zatrzymanych specjalne techniki prowadzenia przesłuchań. Problematyczną kwestią okazały się również prasowe sygnały, iż osoby schwytane w Afganistanie były przetrzymywanie na terytorium Rumunii i Polski w zaimprowizowanych więzieniach oraz poddawane brutalnym przesłuchaniom z użyciem tortur podczas międzylądowań CIA w drodze do Guantána$\mathrm{mo}^{58}$. W tej drugiej sprawie PE powołał specjalną komisję śledczą ${ }^{59}$, a narodowe prokuratury państw oskarżonych o udostępnianie swych baz na terenie UE na potrzeby lotów CIA prowadzą śledztwa ${ }^{60}$. Sytuacja niepokoiła tym bardziej, że władze Stanów Zjednoczonych były oskarżane o jedne z najcięższych zbrodni, a dodatkowo o łamanie prawa międzynarodowego i europejskiego. Przedstawiciele UE sugerują, że postępowanie USA w walce $\mathrm{z}$ terroryzmem osłabi efekty wspólnej polityki USA i UE mającej na celu zdobycie zaufania i szacunku świata muzułmańskiego.

Przedstawiciele administracji G. W. Busha zaprzeczali, jakoby jej funkcjonariusze mieli cokolwiek wspólnego z stosowaniem tortur i łamaniem prawa międzynarodowego.

przewidzianych elementów w przestrzeni orbitalnej, a przedstawiciel Komisji Europejskiej poinformował oficjalnie, że pełna operacyjność systemu Galileo nastąpi najwcześniej w 2016 roku. W 2009 roku pojawił się również problem konfliktu o częstotliwości między Galileo a chińskim systemem Compass (Beidou 2). W 2010 roku po raz kolejny przesunięto datę uruchomienia systemu na lata 2017-2018. Szerzej: http://www.esa.int/esaNA/galileo.html; http:/www.geoforum.pl/?page $=$ news\&id $=6105 \&$ link $=$ Koniec $\% 20$ konfliktu $\% 20 \mathrm{mi} \% \mathrm{C} 4 \% 99 \mathrm{dzy} \% 20 \mathrm{Compassem} \% 20 \mathrm{i} \% 20 \mathrm{Gal}-$ ileo? \&menu=47096\&year $=2009$ \& category $=51(17.12 .2010)$.

${ }_{58}$ Tę wersje zdarzeń potwierdziło śledztwo zorganizowane przez Zgromadzenia Parlamentarnego Rady Europy, które w drugim raporcie z 27 czerwca 2007 roku potwierdziło CIA, iż miała w latach 2003-2005 tajne więzienia w Polsce i Rumunii, w których przetrzymywano osoby podejrzane o terroryzm. W pierwszym raporcie z 7 czerwca 2006 roku na podstawie danych przesłanych z Centrum Satelitarnego UE(EUSC/SETCEN) i Eurocontrol stwierdzono, że: ,jest mało prawdopodobne, by rządy europejskie nie wiedziały o nielegalnej działalności CIA w Europie”, a o pomoc w działalności CIA oskarżono 14. rządów państw członkowskich Rady Europy. Szerzej: E. Żemła, M. Kowalewski, CIA - tajne loty, tajne odprawy, ,Rzeczpospolita”, 30.07.2010.

59 PE postanowił również zająć się lotami CIA w Europie, powołano komisję o nazwie „Rzekome wykorzystanie krajów europejskich przez CIA do transportu i nielegalnego przetrzymywania więźniów". Przed komisją zeznawała była pełnomocniczka lotniska Mariola Przewłocka, która potwierdziła, że w Szymanach lądowały samoloty CIA. Szerzej: Rzekome wykorzystanie krajów europejskich przez CIA do transportu i nielegalnego przetrzymywania więźniów Rezolucja Parlamentu Europejskiego z dnia 19 lutego 2009 r. w sprawie rzekomego wykorzystania krajów europejskich przez CIA do transportu i nielegalnego przetrzymywania więźniów, P6_TA(2009)0073, http://www.europarl.europa.eu/sides/getDoc.do?pubRef=-//EP//NONSGML+TA+P6-TA-2009-0073+0+DOC+PDF+V0//PL (16.03.2011).

${ }^{60} \mathrm{~W}$ grudniu 2010 roku strona amerykańska odmówiła w wyjaśnieniu tej sprawy współpracy z polską prokuraturą. Szerzej: USA nie będa wspótpracować z Polska w sprawie więzień CIA, 28.12.2010, PAP, http://www.orange.pl/kid,4000000150,id,4000528582,title,USA-nie-beda-wspolpracowac-z-Polska-w-sprawie-wiezien-CIA-,article.html (19.12.2010). 
Administracja amerykańska próbowała także zaprzeczać nieludzkiemu traktowaniu więźniów w Guantanamo i przetrzymywaniu ich bez wyroku sądowego. Zapewniając, iż jeżeli będzie to tylko możliwe zwolni więźniów, którzy nie zagrażająjuż bezpieczeństwu USA. Pewien przełom miał nastąpić po zmianie na stanowisku prezydenta USA. Nowy prezydent H. B. Obama zapowiedział 22 stycznia 2009 roku, iż administracja USA zamknie więzienie w Guantanamo do końca 2009 roku. W marcu 2009 roku Departament Stanu USA wyznaczył specjalnego wysłannika, aby przekonał przedstawicieli UE, iż tortury nie były stosowane względem zatrzymanych osób podejrzanych o terroryzm, natomiast część zwolnionych $\mathrm{z}$ więzienia w Guantanamo więźniów mogłaby trafić do państw $\mathrm{UE}^{61}$. Koncepcja administracji H. B. Obamy nie spotkała się $\mathrm{z}$ aprobatą przedstawicieli UE, pomimo deklarowanej jedności w wojnie $\mathrm{z}$ terroryzmem. Różnice zdań pogłębiły uzasadnione obawy, iż wobec osób odpowiedzialnych za stosowanie tortur i przetrzymywanie osób podejrzanych o terroryzm bez wyroku sądu nie zostaną wyciagnięte konsekwencje prawne ${ }^{62}$.

Inną zasadniczą kwestią po 11 września 2001 r. są odmienne punkty widzenia na przyjmowanie regulacji prawnych dotyczących zwalczania terroryzmu. Partnerzy amerykańscy sugerowali w rozmowach z przedstawicielami UE, że podejmowane inicjatywy prawne są pierwszym krokiem w długiej drodze do stworzenia skutecznego antyterrorystycznego ustawodawstwa w ramach UE. Administracja USA była zainteresowana współpracą UE w stworzeniu wspólnych modeli rozwiązań prawnych akceptowanych przez obie strony. Przedstawiciele USA mieli nadzieję, że propozycje współpracy na rzecz ochrony granic i ochrony transportu pomogą przeciwdziałać zagrożeniu terroryzmem i uniemożliwią podejrzanym o terroryzm przyjazd do USA, jak i znalezienie „bezpiecznego azylu” w państwach UE. W tym samym czasie można było zaobserwować we współpracy antyterrorystycznej USA i UE dodatkowe komplikacje wywołane przez różnice w preferencjach poszczególnych podmiotów należących do UE w stosunku do budowy wspólnotowego systemu zwalczania terroryzmu w ramach Unii Europejskiej a oczekiwaniami przedstawicieli administracji USA. Szczególnie było to widoczne w sytuacji, kiedy rozszerzanie obszarów współpracy antyterrorystycznej korelowało z koordynacją wspólnotowej polityki w wielu obszarach na raz np. ochrony praw człowieka i związanym z tym zagadnieniem problemem przechowywania i przesyłania różnego rodzaju danych osobowych, tworzenie i koordynacja punktów odprawy celnej oraz polityki wizowej. Państwa członkowskie UE niejednokrotnie miały problemy z uzgodnieniem wspólnotowych rozwiązań prawnych, dotrzymaniem terminów związanych z ratyfikacją dokumentów i utrzymaniem wspólnego stanowiska w stosunkach z państwami trzecimi. Administracja amerykańska prefero-

${ }^{61}$ Joint Statement of the European Union and its Member States and the United States of America on the Closure of the Guantanamo Bay Detention Facility and Future Counterterrorism Cooperation, Brussels, 11 June 2009 10967/09, http://register.consilium.europa.eu/pdf/en/09/st10/st10967.en09.pdf (18.12.2010).

${ }_{62}$ EU Investigation of CIA Flights May Threaten Intelligence Cooperation, „Associated Press”, February 28, 2007; A. Malcolm, Obama and Guantanamo: A chronology of his broken promise, „Los Angeles Times", 2.07.2010, http://latimesblogs.latimes.com/washington/2010/07/obama-guantanamo.html (18.12.2010). 
wała umowy bilateralne zawierane z poszczególnymi państwami europejskimi (np. VWP). Porozumienia te podważały przeświadczenie o sensowności negocjacji z UE jako globalnym partnerem USA. Z drugiej strony, establishment amerykański wyrażał wolę bliskiej współpracy ze strukturami UE. Było to widoczne w takich sprawach, jak: ustalanie wspólnych antyterrorystycznych praw i umów, kontrola granic i bezpieczeństwa transportu.

$$
* * *
$$

Podsumowując współpracę $\mathrm{w}$ dziedzinie zwalczania terroryzmu należy podkreślić, iż główne problemy w relacjach między Stanami Zjednoczonymi i Unią Europejską zogniskowane są wokół kwestii przestrzegania praw człowieka i podstawowych wolności. Dodatkowo można zauważyć, iż pod koniec pierwszej dekady XXI wieku stopniowo obniża się wiarygodność zimnowojennego dogmatu o transatlantyckiej wspólnocie interesów, ponieważ poruszone kwestie stają się w grze dyplomatycznej zakładnikami swoistej rywalizacji o wypływy w środowisku międzynarodowym. Niewatpliwie do poszerzenia spektrum istniejących rozbieżności przyczyniała się proklamowana i realizowana przez władze amerykańskie GWOT ${ }^{63}$.

Podkreślić należy, iż administracja amerykańska wywołując GWOT zignorowała stanowiska kluczowych przedstawicieli UE, pomimo że dzięki wykorzystaniu przez USA art. 5 Traktatu Północnoatlantyckiego wiele państw z UE (lub państw ubiegających się o członkostwo w UE) należących do NATO znalazło się automatycznie na pierwszej linii frontu. Tym samym UE i jej państwa stały się mimowolnym zakładnikiem amerykańskiej racji stanu. Państwa współtworzące UE zostały potraktowane instrumentalnie, ale w imię tzw. wyższych wartości przyjęły amerykańskie wyzwanie. Pierwsze uderzenie spadło na reżim Talibów w Afganistanie. Większość rządów państw UE poparła działania USA, które z perspektywy ostatniego kwartału 2001 roku stanowiły dla administracji amerykańskiej tzw. ucieczkę do przodu, dzięki odwróceniu uwagi od problemów wewnętrznych USA i pytań o winnych, którzy mogli przez swoje zaniechanie czy brak profesjonalizmu umożliwić przeprowadzenie zamachu na WTC i Pentagon. G. W. Bush dzięki zdecydowanej postawie uzyskał znaczny kredyt zaufania społecznego (notowania jego wzrosły z $40 \%$ do $70 \%$ w sondażach), co w przekonaniu jego administracji stanowiło swoistą legitymizację dla dalszych militarnych inicjatyw. Nawet krytycy amerykańskiego przewodnictwa w środowisku międzynarodowym (zwłaszcza władze FR, jak i ChRL, Francji czy innych państw odnoszących się do realizacji polityki zagranicznej za pomocą środków militarnych z rezerwą) wyrazili zrozumienie dla amerykańskiej operacji i oferowali swoją pomoc. Dzięki sprawnej kampanii propagandowej 11 września $\mathrm{z}$ dnia klęski (kompromitacji całego systemu bezpieczeństwa USA) stał się symbolem walki o „wolność” dla całego demokratycznego świata.

63 Wraz ze zmianą administracji po wyborach 2009 roku w USA termin ten został zastapiony przez „zagraniczne operacje kryzysowe” (ang. Overseas Contingency Operation). Przedstawiciele administracji H. B. Obamy zasugerowali urzędnikom zaprzestanie używania zwrotów: długa wojna (ang. Long War) lub Globalna wojna $\mathrm{z}$ terrorem (ang. GWOT). 
Wraz z upływem kolejnych miesięcy entuzjazm względem działań administracji G. W. Buscha topniał. Zahamowaniu uległa też współpraca z państwami członkowskimi UE i samą Unią Europejską. Szybko okazało się, iż: „dobra wola” deklarowana za każdym razem we wzajemnych relacjach nie wystarczy, kiedy wchodzą w grę różnice w fundamentalnych zasadach systemów prawnych.

Prawdziwy rozłam w ramach NATO i UE ukazujący stosunek USA do swych europejskich sojuszników nastapił po inwazji na Irak. Pomimo sprzeciwu władz francuskich i niemieckich oraz części stałych członków Rady Bezpieczeństwa ONZ, administracja amerykańska rozpoczęła w 2003 roku tzw. drugą wojnę w Zatoce Perskiej. Sprzeciw wobec amerykańskich działań wynikał nie z sympatii do S. Husseina, ale rozległych interesów, które w strategicznych gałęziach gospodarki łączyły Irak z wieloma państwami. Wojna, będąca nowoczesną blitz krieg potwierdziła po raz kolejny militarną potęgę USA. Pod względem politycznym okazała się jednak kompletną kompromitacją. Świadczy o tym stan irackiego państwa osiem lat po amerykańskiej interwencji.

W czasie rozpoczęcia operacji irackiej i pierwszych jej kilkunastu miesiącach stopniowemu pogorszeniu ulegała również sytuacja w Afganistanie, inicjatywę przejmowali częściowo rebelianci utożsamiani z ruchem Talibów. W tym przypadku decyzją Stanów Zjednoczonych było dalsze umiędzynarodowienie konfliktu przez stworzenie zgodnie $\mathrm{z}$ mandatem ONZ sił ISAF pod dowództwem NATO. $\mathrm{W}$ pierwszych latach istnienia siły te miały symboliczny wymiar. Zyskały na znaczeniu dopiero pod koniec pierwszej dekady XXI wieku, kiedy rząd amerykański zmienił strategię i za pomocą taktyki „walca” chce przed planowanym wycofaniem swoich sił zbrojnych z Afganistanu, w najlepszym razie do 2014 roku ostatecznie zniszczyć ogniska oporu.

Ze względu na łamanie międzynarodowego prawa humanitarnego druga wojna w Zatoce Perskiej oraz konflikt w Afganistanie określane są jako „brudne wojny”. W obu konfliktach ze względów finansowych na szeroką skalę władze USA posługują się tzw. prywatnymi firmami wojskowymi (PMC), składającymi się głównie z najemników, którzy naruszają prawa i zasady obowiązujące w czasie trwania konfliktów zbrojnych. Agencje rządowe USA stosowały niekonwencjonalne środki przesłuchań (tortury) wobec pojmanych na froncie irackim czy afgańskich rebeliantów oskarżonych o terroryzm. Skandalem międzynarodowym jest również istnienie więzienia w Guantanamo, gdzie od ośmiu lat dochodzi do łamania podstawowych praw człowieka wobec tam osadzonych więźniów. Kolejną wielką kompromitacją były tajne więzienia CIA na terenie UE (Polska i Rumunia), w których przetrzymywano więźniów pojmanych w Afganistanie w drodze do Guantanamo.

Na ograniczenie kontrowersyjnych działań w ramach GWOT nie wpłynęła zmiana na fotelu prezydenta USA. Wbrew oczekiwaniom obrońców praw człowieka H. B. Obama nie zamknął więzienia w Guantanamo, nie postawił przed sądem urzędników z administracji swojego poprzednika odpowiedzialnych za stosowanie niekonwencjonalnych metod przesłuchań (w tym samego G. W. Busha), nie zakończył amerykańskich operacji w Iraku i Afganistanie (w latach 2009-2010 można było usłyszeć zapowiedzi rozwiązania tych problemów, ale gwarancji ich realizacji nie ma). H. B. Obama nie przerwał również blokady informacyjnej, która jest obecnie najskuteczniejszym na- 
rzędziem w obu konfliktach. Obserwując wydarzenia związane z GWOT można stwierdzić, iż władze USA łamią prawa humanitarne występując $\mathrm{w}$ ich obronie, co Fryderyk W. Nietzsche skwitował, krótką maksymą ,walcząc ze smokami stajemy się nimi”. Jednak trzeba podkreślić, iż władze amerykańskie walczą z przeciwnikiem, który stosując przemoc łamie podstawowe prawa człowieka i zasady humanitarne. Styl, zakres i skuteczność tzw. wojny z terroryzmem pozostawiają wiele do życzenia, lecz do listopada 2010 roku amerykański komponent militarny stosowany jest daleko od granic USA, a dzięki zmianom w postrzeganiu problemu terroryzmu i multiplikacji środków stosowanych do zwalczania tego zjawiska, jak dotąd nie powtórzył się w żadnym miejscu zamach, który skalą dorównywałby temu z 11 września 2001 roku. Można zauważyć konsekwencję w działaniu władz USA, które za pomocą taktyki tzw. kija i marchewki wpływają na środowisko międzynarodowe. W pierwszym przypadku „kijem” jest algorytm nazywany ,globalną wojną z terroryzmem”, za pomocą którego władze Stanów Zjednoczonych modyfikują przestrzeń międzynarodową (pod hasłami: „obrona wartości demokratycznych”, „walka ze złem”, „walka o wolność”). Wojna ta prowadzona w myśl zasady: „kto nie jest z nami, ten przeciwko nam", za pomocą wzmocnień negatywnych spolaryzowała aktorów środowiska międzynarodowego. Przysłowiową ,marchewką” był natomiast projekt tzw. tarczy antyrakietowej, za pomocą której administracja amerykańska wyróżniała szczególnie bliskich sojuszników. Projekt ten postrzegany jako pewna wizja polityczna budowany był na wzmocnieniu pozytywnym i stanowił wartość samą w sobie. Wobec mocarstw rywalizujących z USA projekt tarczy mógł być wyzwaniem strategicznym i pełnić rolę taką samą, jak plan Ronalda Reagana dotyczący rozwijania koncepcji „gwiezdnych wojen”, z tą tylko różnicą że tym razem celem mogły być ChRL i Federacja Rosyjska.

\section{STRESZCZENIE}

Artykuł jest krytycznym spojrzeniem na współpracę w dziedzinie wspólnego zwalczania terroryzmu przez USA i UE. Poruszono w nim najważniejsze kwestie, które stanowią rzeczywiste przeszkody we współpracy obu podmiotów, w przeciwdziałaniu terroryzmowi od początku realizacji przez administrację USA projektu politycznego nazwanego GWOT. Publikacja ma zwrócić uwagę na kwestie rzadko poruszane w głównym nurcie publicystycznym oraz naukowym, które kolidują z zimnowojennym paradygmatem transatlantyckiej wspólnoty wartości. Artykuł ukazuje wyzwania do przezwyciężenia, pomimo politycznych deklaracji przyjmowanych na szczytach USA/UE. Rozważania oparto o teksty źródłowe, aby odbiorca mógł samodzielnie skonfrontować zasadność stawianych tez $\mathrm{z}$ innymi poglądami funkcjonującymi w literaturze, dotyczącymi GWOT i współpracy w tym zakresie między USA i UE. Publikacja ma również zwrócić uwagę na przekaz medialny występujący w środkach publicznych masowego przekazu (szczególnie w Polsce), które ze względu na zaangażowanie władz polskich w GWOT z rzadka poruszają niepoprawne politycznie tematy. Artykuł ma za zadanie skłonić do dalszej pogłębionej refleksji nad rozwojem GWOT oraz dalszymi perspektywami współpracy USA i UE w dziedzinie zwalczania terroryzmu. Artykuł jest wyrazem opinii jego autora, nie stanowiska instytucji, którą reprezentuje. 


\title{
US-EU COUNTER-TERRORISM COOPERATION \\ - TOGETHER DESPITE DIFFERENCES (2001-2010)
}

\begin{abstract}
The article takes a critical viewpoint on the shared co-operation in the area of fighting terrorism by the USA and the EU. The most important issues are raised, which constitute real obstacles in the co-operation of both subjects, in the counteracting the terrorism since the beginning of the political project's realization by administration of the USA, the political project called GWOT. The publication points out issues only occasionally raised in the journalistic and scientific mainstream, which collide with the cold-war paradigm of the transatlantic community of values. The article aims to raise awareness of the challenges, despite political declarations consistently accepted during the USA/EU summits. The Narrations are based on international documents, so that a recipient could confront independently the legitimacy of proposed theses with other existing in the literature articles, articles concerning GWOT and co-operation in the scope of the USA and EU. The publication points out the modus operandi of the mass media (especially in Poland), which on account of Polish authorities involvement in GWOT, very occasionally raise the politically incorrect subjects. The article aims to generate further detailed reflection on GWOT's evolution and the further co-operation of the USA and UE in the area of fighting terrorism.
\end{abstract}


